\title{
Teaching Interlanguage Pragmatics to Ukrainian Student Translators From English
}

\author{
M. Vozna
}

Taras Shevchenko National University of Kyiv, Kyiv, Ukraine

Corresponding author. E-mail: haponievalex@gmail.com

Paper received 24.01.18; Revised 27.01.18; Accepted for publication 28.01.18.

https://doi.org/10.31174/SEND-PP2018-154VI64-14

Abstract. The article researches the issues of interlanguage pragmatics from the pedagogical point of view. It describes a teaching experiment held at Taras Shevchenko National University of Kyiv, where the principle of explicit teaching with especial focus on pragmatic factors was applied to teaching translation from English into Ukrainian and vice versa to Ukrainian MA students, which showed a significant positive influence of the consistent application of this method by the teacher on the students' awareness of pragmatic issues in translation.

Keywords: interlanguage pragmatics, explicit teaching, teaching experiment, pragmatic awareness, consecutive translation.

Introduction. The field of pragmatic studies has been actively researched for many decades now, which is not surprising given its not only academic but also practical importance. The renowned scholar David Crystal wrote in one of his ground-breaking works on English as a global language: "Pragmatics is the study of language from the point of view of users, especially of the choices they make, the constraints they encounter in using language in social interaction and the effects their use of language has on other participants in the act of communication" $[1, \mathrm{p}$. 301]. This language-in-use approach is of particular importance to those professionals who deal with language use on a daily basis, facilitating communication between nations and individuals, the translators, and those educationalists who teach them translation. Both groups have to have knowledge in pragmatics theory for the purposes of practicing translation and education.

Short review of publications. The focus in pragmatic studies has long moved from studying speech acts in one separate language understood as literally doing things with words to a much broader understanding of pragmatics as learning how the choice of words and language structures can successfully influence a particular effect by the speaker on the targeted audience, if such speaker consciously or subconsciously takes into account social and ideological factors, the nationality, culture, age, gender and expert or background knowledge of the audience. Their choice of words and language structures would also be governed by what style the speaker wants to communicate in: formal or informal, orally or in writing, how accurate their words must be, whether broad or simplifies vocabulary must be used, whether English is a native language for the targeted audience or not, and how far their native language and culture is from the speaker's.

In this respect a very productive field in pragmatic studies in the last two decades was found to be where participants in communication have different first languages and represent different cultures, and where merging, crossing and blending of cultures takes place. Two relatively new lines of research have established themselves in linguistics, those of cross-cultural pragmatics and intercultural pragmatics $[2 ; 3]$, which have led to the foundation of a specialized journal called "Intercultural Pragmatics". The two fields are close, but not identical. One of the major academics in these two fields compares them in the following way: "While cross-cultural pragmatics compares different cultures, based on the investi- gation of certain aspects of language use, such as speech acts, behaviour patterns, and language behaviour, intercultural pragmatics focuses on intercultural interactions and investigates the nature of the communicative process among people from different cultures, speaking different first languages. Cross-cultural pragmatics analyses the differences and similarities in the language behaviour of people representing different languages and cultures. Intercultural pragmatics, however-a relatively new discipline - is interested in what happens when representatives of different first languages and cultures communicate using a common language" [3, p.400].

Culture is, obviously, a key word in the above definitions and understanding what culture is for pragmatics studies draws the attention of academics from the very beginning. Two principally different approaches were taken on culture: one of culture being exclusively situational, depending on the context of communication [4]; the other of "culture being characterized by both regularity and variety" [3]. Istvan Kecskes says in this respect: "It (culture) is more than just an online created and co-constructed phenomenon. In communication, interlocutors can rely on two types of repository of prior experience and encounters: lexical units and communicative styles. Like lexical items, cultural patterns (often expressed in different communicative styles) code prior experience and encounters, i.e. relatively standard cultural behaviour models and expectations which are activated in the given actual situational context. In the course of interaction these existing models are modified and blended with situationally emergent new elements. This process of blending that relies both on existing and emerging factors constitutes the communicative encounter. Blending means smoothly joining these elements and/or factors into new intercultures [3, p. 405].

Another important factor of intercultural communication, studied extensively within socio-cognitive paradigms, is that of the individuals participating in an act of communication. Their desire to achieve cooperation in communication is counterbalanced by their personal goals, intentions and feelings. They rely both on their prior knowledge and experience, in terms of language and culture, which represent certain language and cultural norms, and at the same time create ad hoc patterns and models of language behavior suitable for particular acts of communication. This blending of features in a synergetic 
way manifests interculturality in the process of communication.

Such intercultural interaction between representatives of different languages and cultures cannot fail to be of particular interest to language educators and translators, since their major goal is to ensure that such intercultural communication is successful. Thus, the approach of explicit teaching of intercultural pragmatics to secondlanguage learners and, specifically, to future translators, whose task is to apply such knowledge in their professional life, comes to the fore.

In translation studies the concept of "invisible translator" was replaced by the concept of "agents of change" [5, p.1], translators, whose active role makes a difference, who "propagate ideas and knowledge by crossing cultural boundaries" [5, p.3]. In communicative translation studies "The translator is regarded as an independent expert, a cultural mediator who has the authority to carry responsibility for the target text... Translatorial skills are not purely linguistic, either; they include the ability to find necessary background information ...estimate the degree of cultural adaptation needed, and so on" [5, p.31]. In fact, a translator should pay attention to many more pragmatic factors during the process of translation, discussed in this article. The awareness of such pragmatic factors definitely requires a certain theoretical background from the translator. Andrew Chesterman wrote in this respect: "A translator must have a theory. Theoretical concepts are essential tools for decision making during the translation process" [5, p.2]. He further wrote: "Indeed, awareness of theory in general, of the explanatory power of the theoretical concepts is widely accepted as an important part of professional training in any field, and scarcely needs to be justified separately in translator training..." [5, p.150].

In this respect, it must be noted that although general pragmatic principles have long been introduced into teaching practices in many countries of the world, including Ukraine, the focus in them has shifted from teaching students expressive positively or negatively coloured lexis and speech formulas [6] to making students choose and justify their translator's decisions on culture-specific vocabulary [7], adaptation of their translations to take into account a whole number of pragmatic factors, such as whether the targeted audience is professional or not, its age, culture and nationality characteristics, whether translation is written or oral, whether the situation of communication is formal or informal, whether the translator wants to stay neutral (which they should) or should they choose a different approach, and other considerations. In oral translation, again, decisions would depend on whether the translation is simultaneous or consecutive; the latter gives more room for explanatory translation and in certain situations the opportunity for the translator to correct themselves.

Despite the general interest in translation and pedagogical studies to the named issues, traditionally in Ukraine more emphasis was laid on teaching how to translate literary works, and much research and teaching effort was devoted to the issues of written translation to the detriment of oral one. Teaching materials for oral translation that would focus the teaching process specifically onto pragmatic issues are lacking. This situation does not meet the requirements of today and the current situation in the translation markets in Ukraine where oral and written, pragmatically aware, translation in many professional areas is in high demand, whereas the segment of literature translation from Ukrainian and into Ukrainian continues to be insignificant.

Thus, in our opinion, research into teaching principles and methods, which may form a foundation for pragmatically focused teaching materials in oral translation is long overdue. This has led us to undertake a study into the challenges of teaching pragmatically-aware consecutive translation to Ukrainian MA students, which included a teaching experiment.

The results of the research. Our study was based on the long accepted postulate in translation theory that no one single correct translation exists, that translators must, in fact, make a number of choices as to the strategy and methods of translation, to factor in, among other things, pragmatic parameters, which means that a number of correct or faithful translations may exist. This approach stresses the creative character of a translator's work and the active role of the translator as an individual in the process of translation. Such a conscious approach means that the translator should not only creatively re-express the original message, but be able to justify their choices. Both translators and translation teachers "need to constantly improve their operative (know how) and declarative (know what) knowledge. Consequently, one of the main aims of the teacher's job is to help the students acquire and improve both kinds of knowledge. While it often happens that full-time translators may experiment difficulty in verbalizing their declarative and operative knowledge, probably because they have become automatized, teachers, on the other hand, they should, in our view, be able to verbalize and transmit knowledge so that the students' attitude and aptitude towards the subject can improve" [8, p.161]. The principle of explicit teaching described above has served as the major tool and goal of the study undertaken.

A hypothesis was formulated that explicit teaching focusing, among other things, on pragmatic parameters improves a student's awareness of the translation processes, leading to better quality translation results.

The tasks of the study and experiment were to:

- Determine the most common problems Ukrainian MA students experience in translating consecutively from English into Ukrainian and from Ukrainian into English.

- Create teaching materials specifically focusing on pragmatic parameters.

- Monitor the improvement of the general quality of students' translations after such teaching materials have been introduced.

- Assess the change in the degree of students' awareness of translation processes at the end of the course.

The experiment was held in a group of 22-year old students on a Master's course in translation at the Department of Theory and Practice of Translation from English at Kyiv National Taras Shevchenko University of Ukraine. The subject of oral translation comprised 60 hours taught during one semester.

To determine major challenges and monitor how students overcame these, they were asked to fill out written questionnaires during the whole of the course, which included their commentary on the following issues: 
- Spotting major problems. Based on the teacher's previous experience, especial focus was laid on spotting professional jargon and cultural references. Students were also asked to specify at what point they have spotted a problem: a) at an early stage of having just heard a foreign word which they have not recognized or b) at a later stage when they have realized that what they thought of as the lexical unit did not fit the particular context and/or does not make any or much sense.

- Choosing a strategy, which in many academic sources may be called "a general approach". In this section students had to comment on what their strategic approach to a particular translation was. Given the fact that we are talking about consecutive translation where the whole text was not presented to students at once but was received in small portions due to the nature of this type of translation, strategic decisions had on the whole to be made in advance, and then only adjusted in the process of actual translation. The students might have decided to make the text closer to the targeted audience (domestication strategy), or preserving its foreign colour (foreignisation), making it sound American or British, simplify and explain in translation for non-professional audience, adjust their translation for age, sex, culture of the targeted audience, making it sound formal or conversational depending of the communication situation, and other.

- Choosing the method of translation. In this section the students had to comment upon what decisions they had made to implement the chosen strategy. Their options might have been transcoding, literal translation, explanatory translation, analogous translation, choosing the best dictionary equivalent, contextual translation, and others including combined methods if necessary.

- Students' translation version.

- Justification of the chosen method and version.

In the class room consecutive translation, the pragmatic parameters that would enable students to make a correct decision on their general strategy and methods, and, subsequently, offer their own version of translation for a particular lexical unit, must be set by the teacher. Focusing on such parameters represented an element of explicit teaching aimed at raising students' awareness of the pragmatic issues in translation. This approach was achieved through the introduction of particular tasks setting the pragmatic parameters of a certain translation context, for example:

- Translate consecutively the following lecture by Prof. J. Wells on the current state of English phonetics for an audience of linguistic students at a university in Kyiv. (Here students may choose not to explain terminology and linguistic jargon as the speaker talks in front of an expert audience in his particular professional field).

- Translate consecutively the following presentation by an American lawyer on non-agricultural land privatization in front of an audience of land surveyors and village and town councilors. (Here students must consider explanatory translation for certain professional jargon as the audience is partially non-professional, and terminological systems may not map onto each other due to significant discrepancies between the concepts in this particular professional area).

- Translate consecutively from English and from Ukrainian an informal meeting between a visiting British banking expert and a group of Ukrainian bankers. (Here students have to take into account that the visitor may have little knowledge of the Ukrainian environment, hence they must consider domestication strategy in translation which may be implemented through analogous or explanatory translation and not translating for foreigners who have long been living in Ukraine. Students must also consider that the visitor is British and not American, and thus opt for British English versus American English. They also must realize that the informal situation of communication gives them an advantage of being able to ask for rephrasing or repetition if an information gap occurred.)

- Translate consecutively a talk by an English writer of children's books in front of an audience of Ukrainian junior schoolchildren. (Here domestication strategy must be considered to make the original text closer to children. The translation must also be adapted for their age.)

- Translate consecutively the following video-material about female officers serving in the Ukrainian Armed Forces into English. (Here the students must show gender awareness in translation. They must also think of the style of their translation, as servicewomen may choose to speak in a highly conversational style, using military jargon or slang, which to a certain degree must be reflected in translation).

- Translate consecutively the following pressconference by a Ukrainian Armed Forces public relations officer in front of a group of foreign journalists. (Here the students must consider the choice of politically and ideologically-biased vocabulary in translation of not only general but also military terms and expression to make sure that the targeted audience understands on whose side the translator is on. I believe that in certain situations neutrality in translation may be abandoned).

Video- and audio-materials were selected to practice consecutive translation in various professional areas, such as: academic research and education, popular science (history, linguistics, literature studies), art, business, warfare, politics, environmental protection, local and national government, banking, etc.

Students were given a test of pragmatically aware translation at the beginning and at the end of the course with objective assessment of consecutive translation by the teacher and writing down comments similar to described in the above discussed written protocols. Teacher's notes were also continuously taken to monitor the pragmatic awareness levels.

The analysis of the student's written protocols, test results and teacher's notes enabled us to come to the following conclusions:

- At the beginning of the teaching experiment approximately $70 \%$ of information gaps resulted from the nonrecognition of professional jargon or cultural references (20\%) and rare, learned words (10\%).

- Only $50 \%$ of lexical units were spotted early as problems for translation, i.e. were not recognized at the stage of listening comprehension, and 50\% were recognized as problems at the later stage of trying to identify their sense in a particular context.

- Only in 35\% of instances students were able to formulate at least partially the strategy chosen for their translation, although in over $80 \%$ of instances the students 
were able to correctly determine and apply a particular translation method.

- In only approximately $20 \%$ of instances the students were able to justify their choice of the strategy and the applied method of translation.

At the end of the experiment the first position results remained mostly unchanged, since listening comprehension of students and their knowledge of the language, as well as their background knowledge in particular areas of human activity belong to "know what" knowledge that is acquired throughout the whole period of tuition in learning all linguistic and other related disciplines and then throughout their professional lives. Thus, it cannot be easily improved throughout a short translation course.

At the same time the results of being able to correctly choose and apply a strategy and a method of translation improved almost by $50 \%$, and the attempts to justify the chosen strategy and method were adequate in $40 \%$ of instances, which is twice as much as at the beginning of the experiment.

Conclusions. Thus, the results of the teaching experiment and research have demonstrated the correctness of the formulated hypothesis that explicit teaching, focusing on various pragmatic factors, brings positive results in raising the general pragmatic awareness of students, future translators, and is an effective teacher's tool to be applied in teaching English and translation from English and into English to future professionals: an instrument to improve their "know how" professional skills. Teaching materials used in this experiment may be used as guidelines for other translation teachers and other courses, especially in oral translation, to focus students' attention on a wide range of pragmatic factors to be taken into account when translating from and into English.

\section{REFERENCES}

1. Crystal, D. English as a global language. - Cambridge: Cambridge University Press, 1997.

2. Kecskes, I. Intercultural Pragmatics. - Oxford: Oxford University Press, 2013. - 288pp.

3. Kecskes, I. Cross-Cultural and Intercultural Pragmatics //The Oxford Handbook of Pragmatics. - Oxford: Oxford University Press, 2017. - P.400-412.

4. Evans, V., Pourcel S. New Directions in Cognitive Linguistics, 2009. - 519pp.

5. Chesterman, A. Memes of Translation: The Spread of Ideas in Translation Theory. - Amsterdam/Philadelphia: John Benjamins Publishing Company, 2016. - 225 pp.

6. Григораш, Г.Ф., Шиманский В.С., Костина Л.Т. Коммуникативно-прагматический анализ текста как средство повышения эффективности занятий по иностранному языку //Вестник Киевского университета. Романогерманская филология. - Вып. 22. - 1988. - С.101-106.

7. Зорівчак Р.П. Реалія і переклад. - Львів: Видавництво при Львівському державному університеті, 1989. - 210с.

8. González Davies, M., Scott-Tennent C. A Problem-Solving and Student-Centred Approach to the Translation of Cultural References//Meta: Translators' Journal. - Vol. 50, No 1. 2005. - Pp. 160-179.

6. Hryhorash H., Shymansky V., Kostina L. Communicative and Pragmatic Text Analysis as a Tool in Raising the Efficiency of Foreign Languages' Teaching// Kyiv University Bulletin. Romanic and Germanic Languages. - Vol.22. - 1988. Pp.101-106.

\section{Обучения украинских студентов переводческих отделений на принципах межязыковой прагматики \\ М. Возна}

Аннотация. В статье рассматриваются вопросы межязыковой прагматики с педагогической точки зрения. Статья описывает результаты педагогического эксперимента, проведенного в Киевском национальном университете имени Тараса Шевченко, в котором было доказано общее позитивное влияние последовательного применения принципа эксплицитного обучения с особым акцентом на прагматических факторах на процесс обучения переводу с английского языка на украинский язык и наоборот в группе студентов-магистров, чей уровень осознанности прагматических факторов в процессе перевода значительно вырос на момент окончания эксперимента.

Ключевые слова: межязыковая прагматика, эксплицитное обучение, педагогический эксперимент, осознанность прагматических факторов, последовательный перевод. 